\title{
Temperature influence on the natural aerosol budget over boreal forests
}

\author{
L. Liao ${ }^{1}$, V.-M. Kerminen ${ }^{1}$, M. Boy ${ }^{1}$, M. Kulmala ${ }^{1}$, and M. Dal Maso ${ }^{2}$ \\ ${ }^{1}$ Department of Physics, University of Helsinki, P.O. Box 64, 00014, Helsinki, Finland \\ ${ }^{2}$ Department of Physics, Tampere University of Technology, P.O. Box 692, 33101, Tampere, Finland \\ Correspondence to: L. Liao (li.liao@helsinki.fi)
}

Received: 2 September 2013 - Published in Atmos. Chem. Phys. Discuss.: 19 December 2013

Revised: 4 July 2014 - Accepted: 13 July 2014 - Published: 19 August 2014

\begin{abstract}
We investigated the natural aerosol evolution of biogenic monoterpene emissions over the northern boreal forest area as a function of temperature using long-term field measurements of aerosol size distributions and back trajectories at two SMEAR (Station for Measuring EcosystemAtmosphere Relations) stations, SMEAR I and SMEAR II, in Finland. Similar to earlier studies, we found that new particles were formed via nucleation when originally clean air from the ocean entered the land, after which these particles continuously grew to larger sizes during the air mass transport. Both the travelling hour over land and temperature influenced the evolution of the particle number size distribution and aerosol mass yield from biogenic emissions. Average concentrations of nucleation mode particles were higher at lower temperatures, whereas the opposite was true for accumulation mode particles. Thus, more cloud condensation nuclei $(\mathrm{CCN})$ may be formed at higher temperatures. The overall apparent aerosol yield, derived from the aerosol masses against accumulated monoterpene emissions, ranges from 13 to $37 \%$ with a minor, yet complicating, temperature dependence.
\end{abstract}

\section{Introduction}

Natural aerosol particles - including sea spray, mineral dust, and primary and secondary biogenic particles - are central to our understanding of the earth's climate system (Carslaw et al., 2010). This is, first of all, because the atmospheric concentration levels and properties of natural aerosols need to be known in order to determine which fraction of the atmospheric aerosol is of anthropogenic origin. Separating natural and anthropogenic aerosols and their precursors is extremely challenging, since they may interact with each other in complicated ways (e.g. Dentener et al., 1996; Hoyle et al., 2011). Second of all, natural aerosol particles are part of various climate feedback loops, as their future concentration levels are expected to change with changing climate conditions (Arneth et al., 2010; Carslaw et al., 2010; Korhonen et al., 2010; Quinn and Bates, 2011; Kulmala et al., 2004, 2013).

Biogenic secondary organic aerosol (BSOA) originating from biogenic emission presents a major fraction to the global submicron aerosol budget (Kanakidou et al., 2005; Goldstein and Galbally, 2007). The BSOA affects climate directly by scattering solar radiation and indirectly by aerosolcloud interactions (e.g. Makkonen et al., 2012). The latter effect is tied strongly with atmospheric cloud condensation nuclei $(\mathrm{CCN})$ production, and thereby also with atmospheric new particle formation and growth (Riipinen et al., 2011; Yu, 2011; Kerminen et al., 2012; Makkonen et al., 2012). Since potential BSOA precursor emissions from terrestrial ecosystems strongly increase with increasing temperatures (Guenther et al., 2012), the natural $\mathrm{CCN}$ production associated with BSOA may be enhanced in warmer future climate, which would lead to a negative climate feedback mechanism (Kulmala et al., 2004). Recent observations and model simulations show support for the enhanced BSOA formation due to higher temperatures (Day and Pandis, 2011; Leaitch et al., 2011; Miyazaki et al., 2012; Makkonen et al., 2012; Paasonen et al., 2013), yet the exact relation between the ambient temperature, BSOA formation and natural $\mathrm{CCN}$ concentration levels is far from resolved. A major reason for this is that the temperature influences not only the BSOA precursor emissions, but also their atmospheric oxidation, resulting 
in gas-particle partitioning and potential heterogeneous reaction in the particle phase (Kroll and Seinfeld, 2008; Hallquist et al., 2009; Donahue et al., 2012; Riipinen et al., 2012).

Boreal forests are believed to be globally one of the most important sources of BSOA precursors (Spracklen et al., 2008; Tunved et al., 2006). Field measurements have shown that clean air masses arriving at the boreal forest zone experience a notable BSOA and $\mathrm{CCN}$ concentration increase during the summer part of the year (Tunved et al., 2006; Lihavainen et al., 2009), with subsequent implications for aerosol-cloud interactions (Spracklen et al., 2008). Tunved et al. (2008) investigated future BSOA production over the boreal forest area by extrapolating the emissions with a projected temperature increase, but did not consider the complicated nature of the various temperature impacts.

BSOA formation is often treated by considering the aerosol mass yield, namely the fraction of precursor VOC that forms aerosol mass. Biogenic monoterpenes are the most commonly assumed aerosol precursors, while other precursor vapours are also considered to play a role (Mentel et al., 2009). However, large-scale models simulating SOA formation on a global scale often only use monoterpenes as the organic precursor, especially for BSOA, even though the fraction of monoterpenes producing aerosol is not yet well constrained (e.g. Spracklen et al., 2008; Makkonen et al., 2012).

The idea behind this study is similar to that of Tunved et al. (2006, 2008), namely to classify observations at field stations by the amount of time air masses have spent over the boreal forest, and then to estimate the emissions of biogenic aerosol precursor vapours, and finally to connect these quantities to aerosol observations. A clear connection was established in these earlier studies. Furthermore, Tunved et al. (2008) provided a parameterization where the effect of a temperature increase on the aerosol size distribution was taken into account. The parameterization assumed that temperature only affected the biogenic VOC emission. However, it is likely that a change in temperature will also change the VOC conversion efficiency (aerosol yield) into aerosol particles. In this study, we attempt to use similar methods to establish whether this temperature effect on the aerosol yield can be observed in the data. In addition, the studies of Tunved et al. $(2006,2008)$ did not account for particle losses during transport to the site. By estimating these losses, we can obtain an upper-limit estimate for the conversion rate of biogenic emissions into aerosol during transport to the measurement site.

\section{Measurements and methods}

We use a previously developed (Tunved et al., 2006) and tested (Tunved et al., 2008) method, focusing on the observed temperature impacts at five ascending temperature bins to the natural aerosol loading in this study. The basis setup of the approach is to investigate the characteristic evolution of aerosol population in air parcels through clean marine to con- tinental transition over northern boreal forest area. We study the particle-size distribution and mass evolution as a function of time spent over land, and then we link them to the estimated cumulative monoterpene emissions during the air transport (Tunved et al., 2008).

\subsection{Measurement description}

The data set was based on the observations at two Finnish SMEAR (Station for Measuring Ecosystem-Atmosphere Relations Hari and Kulmala, 2005) stations: SMEAR I $\left(67^{\circ} 46^{\prime} \mathrm{N}, 29^{\circ} 35^{\prime} \mathrm{E}, 400 \mathrm{~m}\right.$ a.s.1.) in Värriö, and SMEAR II $\left(61^{\circ} 51^{\prime} \mathrm{N}, 24^{\circ} 17^{\prime} \mathrm{E}, 170 \mathrm{~m}\right.$ a.s.l.) in Hyytiålå, Finland. A $13-$ year data set from 1998 to 2010 at the SMEAR I station and 15-year data set between 1996 and 2010 at the SMEAR II station, based on continuous differential mobility particle sizer (DMPS) measurements, were used together with backward trajectory data.

At SMEAR II, the DMPS system measured atmospheric particle-size distributions from 3 to $1000 \mathrm{~nm}$ during the whole observation period, whereas, at the SMEAR I station, particles from sizes 8 to $460 \mathrm{~nm}$ were measured before April 2003, and the system was then extended to the same particlesize range as in SMEAR II (Dal Maso et al., 2007). We used particle sizes smaller than $450 \mathrm{~nm}$ in all calculations to keep the data consistency. Particle size spectrums were divided into three size modes: nucleation mode with particle diameters $\left(D_{\mathrm{p}}\right)<25 \mathrm{~nm}$, Aitken mode $\left(25<D_{\mathrm{p}}<100 \mathrm{~nm}\right)$ and accumulation mode $\left(D_{\mathrm{p}}>100 \mathrm{~nm}\right)$. Particle number concentrations at each mode were calculated for every 1-hour period, averaging from 15 min DMPS measurements. Hourly particle volume concentrations were integrated from the DMPS size distributions assuming spherical particles. Also, the hourly total aerosol masses were calculated from the total aerosol volume concentrations, applying a constant aerosol density ( $\rho=1500 \mathrm{~kg} \mathrm{~m}^{-3}$ Kostenidou et al., 2007).

\subsection{Backward trajectories}

The hourly $96 \mathrm{~h}$ backward trajectories arriving at $100 \mathrm{~m}$ a.g.l. over the SMEAR I and SMEAR II stations were calculated from the HYSPLIT4 model (Draxler and Hess, 1997) during the whole measurement period. The uncertainty of the trajectory calculations has been estimated to be $10-30 \%$ of the travel distance (Draxler and Hess, 1998; Heinzerling, 2004). Each individual travel point of the backward trajectories also included the air temperature at the travelling height, mixing layer height, solar flux, precipitation, pressure and relative humidity. All the meteorological data in the trajectory calculations were from a global data assimilation system (GDAS) reanalysis archive for data sets after 2004, and from a FNL (Final) archive for data sets before 2004, provided by the NCEP (National Centre of Environmental Predictions). The uncertainty of the meteorological data set has been minimized within the GDAS and FNL reanalysis archive, as it has 


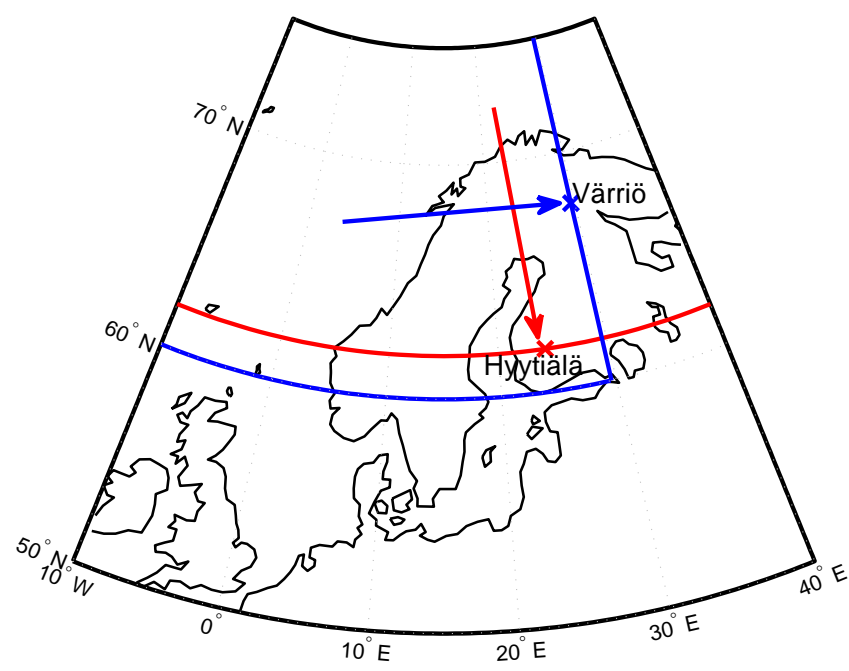

Figure 1. The transport sectors of back trajectories at the two Finnish SMEAR stations. Area above the red line is the travelling zone of selected trajectories arriving at the SMEAR II station. The blue sector covers the transport area of trajectories arriving at the SMEAR I station. At both stations, each trajectory should spend at least $90 \%$ of travelling time inside the transport sectors.

combined all the available ground measurements and satellite observations. The travelling time over ocean or land for each trajectory was determined from topographical data. The ground-level temperature was calculated from the air temperature of each trajectory travel point at the actual height by using a lapse rate of $0.65^{\circ} \mathrm{C}$ per $100 \mathrm{~m}$ (Finlayson-Pitts and Pitts, 2000), which was the same approach in Tunved et al. (2008).

Trajectories from April to September each year were used. The reasons for that were to guarantee significant monoterpene emissions, to exclude seasonal dependence of the aerosol population evolution at the receptor sites, and to minimize anthropogenic influence that was significant in winter. A more detailed explanation of the approach can be found from the supporting text by Tunved et al. (2006).

Several criteria, similar to those in Tunved et al. (2008), were used to select the back trajectories for our analysis. (1) Wide transport sections of back trajectories were chosen covering mostly clean boreal forest area without anthropogenic influence from southwest Europe. These include one $180^{\circ}$ transport sector $180^{\circ} \mathrm{S}-0^{\circ} \mathrm{N}$ relative to Värriö, and travelled only above $60^{\circ} \mathrm{N}$ at the SMEAR I station, and one $180^{\circ}$ transport sector $90^{\circ} \mathrm{W}-90^{\circ} \mathrm{E}$ relative to Hyytiåla at the SMEAR II station, seen in Fig. 1. (2) Each trajectory had to spend its first 5 hours over ocean and travelled at least $90 \%$ of time inside the transport sectors. (3) Assuming an imaginary air parcel travelling along the trajectory, its travelling height had to be continuously below the mixing layer height over the land area. Compared to the previous studies, we narrowed down our trajectory selections by adding the third cri- terion, for the reason that this criterion would be in line with the following calculation of monoterpene emissions.

The total numbers of trajectories from extractions were 6481 for the SMEAR I station and 5086 for the SMEAR II station. For each selected trajectory, the average trajectory temperature was calculated from the estimated ground level temperature at all end points travelling over land along the whole trajectory. To investigate the aerosol characteristics under different temperature conditions, we classified all the selected trajectories into five groups by separating their corresponding average trajectory temperature equally into five bins from 0 to $20^{\circ} \mathrm{C}$ for both stations in this study.

\subsection{Calculation of monoterpene emissions}

Previous studies have shown that monoterpene emissions are strongly temperature dependent and can be described well by a temperature dependent emission algorithm (Bertin et al., 1997; Tarvainen et al., 2005). The predicted monoterpene emissions from the simple temperature dependent emission algorithm have shown the correlation of up to $R^{2}=0.96$ with measurements (Tarvainen et al., 2005). We applied a similar algorithm in this study, and the total flux of monoterpenes was derived from the following equation (Steinbrecher et al., 1999):

$F=\varepsilon D \gamma$,

where $F\left(\mu \mathrm{g} \mathrm{m}^{-2} \mathrm{~h}^{-1}\right)$ is the total flux of monoterpenes from the boreal forest, $\varepsilon$ is the emission potential for coniferous species, with value $1.5 \mu \mathrm{gg}$ (dry weight $)^{-1} \mathrm{~h}^{-1}$, and $D$ is the foliar biomass density. Here, we used a foliar biomass density of $54 \%$ pine and $46 \%$ spruce as a function of latitude in northern European boreal forest zone (Lindfors et al., 1999). $\gamma$ is an environmental correction taking into account the temperature dependency of monoterpene emission rate. It can be calculated from $\gamma=\exp \left(\beta\left(T-T_{\mathrm{S}}\right)\right)$, where $\beta=0.09^{\circ} \mathrm{C}^{-1}$ and $T_{\mathrm{S}}=303.15 \mathrm{~K}$. We omitted the leaf temperature to simplify the calculation and used the estimated ground-level temperature $(T)$ from the meteorological profiles along each trajectory.

By assuming that monoterpene emissions were well confined within the well-mixed boundary layer, the concentration increment of monoterpene emissions per unit volume during transport over land $(E)$ can be derived by $E=F / L$, where $L$ is the boundary layer height. Monoterpene emissions from the ocean were set to zero, and the accumulated monoterpene emissions were calculated for each trajectory spent over land, disregarding the short lifetime of monoterpenes in air. 
Table 1. Growth rate fitting parameters and condensation sink values in the five temperature bins, as well as from the whole data set both at the SMEAR I and the SMEAR II stations.

\begin{tabular}{lcccccc}
\hline SMEAR II, Hyytiälä & & & & & & \\
Temperature bin $\left({ }^{\circ} \mathrm{C}\right)$ & $0-4$ & $4-8$ & $8-12$ & $12-16$ & $16-20$ & All \\
\hline Initial diameter $(\mathrm{nm})$ & 18.3 & 24.7 & 29.5 & 46.6 & 80.1 & 25.1 \\
$D_{\mathrm{p}}$ at Hour-10 $(\mathrm{nm})$ & 17.4 & 23.0 & 25.7 & 43.4 & 12.1 & 24.7 \\
Initial hour $(\mathrm{h})$ & 13 & 14 & 16 & 16 & 53 & 11 \\
Final diameter $(\mathrm{nm})$ & 40.9 & 55.3 & 77.5 & 86.9 & 130.6 & 59.5 \\
Final hour $(\mathrm{h})$ & 87 & 85 & 91 & 91 & 85 & 91 \\
Growth rate $\left(\mathrm{nm} \mathrm{h}^{-1}\right)$ & 0.31 & 0.43 & 0.64 & 0.54 & 1.58 & 0.43 \\
Median CS $\left(\mathrm{s}^{-1}\right)$ & $1.37 \times 10^{-3}$ & $1.44 \times 10^{-3}$ & $2.30 \times 10^{-3}$ & $2.88 \times 10^{-3}$ & $3.61 \times 10^{-3}$ & $1.82 \times 10^{-3}$ \\
\hline SMEAR I, Värriö & & & & & & \\
Temperature bin $\left({ }^{\circ} \mathrm{C}\right)$ & $0-4$ & $4-8$ & $8-12$ & $12-16$ & $16-20$ & All \\
\hline Initial diameter $(\mathrm{nm})$ & 19.6 & 28.0 & 32.7 & 55.0 & - & 24.3 \\
$D_{\mathrm{p}}$ at Hour-10 $(\mathrm{nm})$ & 20.0 & 27.6 & 30.8 & 39.9 & - & 23.7 \\
Initial hour $(\mathrm{h})$ & 9 & 11 & 13 & 28 & - & 11 \\
Final diameter $(\mathrm{nm})$ & 48.8 & 60.9 & 82.8 & 107.3 & - & 69.2 \\
Final hour $(\mathrm{h})$ & 88 & 92 & 90 & 90 & - & 91 \\
Growth rate $\left(\mathrm{nm} \mathrm{h}^{-1}\right)$ & 0.37 & 0.41 & 0.65 & 0.84 & - & 0.56 \\
Median CS $\left(\mathrm{s}^{-1}\right)$ & $7.01 \times 10^{-4}$ & $9.98 \times 10^{-4}$ & $1.65 \times 10^{-3}$ & $2.42 \times 10^{-3}$ & - & $1.36 \times 10^{-3}$ \\
\hline
\end{tabular}

\section{Results and discussion}

\subsection{Formation of secondary organic aerosol}

\subsubsection{Aerosol mass gain with transport over land}

We binned all the trajectories based on their travelling hours over land $\left(t_{\text {hol }}\right)$ before arriving at the receptor sites, and calculated the average aerosol mass for each hourly bin. The average aerosol mass was only given if there were at least 10 trajectories travelling the same $t_{\text {hol }}$. The averaged aerosol masses as a function of $t_{\text {hol }}$ are depicted both for the SMEAR II station and the SMEAR I station in Fig. 2. The aerosol mass increased linearly with $t_{\text {hol }}$ at these two stations, and the correlation coefficients $R^{2}$ between these two quantities were 0.75 at the SMEAR I station and 0.90 at the SMEAR II station. The linear fitting slopes indicating the average mass gain per hour at the receptor stations were $0.02 \mu \mathrm{g} \mathrm{m}^{-3}$ per hour at the SMEAR I station and $0.04 \mu \mathrm{g} \mathrm{m}^{-3}$ per hour at the SMEAR II station. The average aerosol mass increments per hour are $43 \%$ higher than those previously found for both stations by Tunved et al. (2006) (see the fitting slope comparisons with dashed lines in Fig. 2), but are close to the result reported by Tunved et al. (2008) for the SMEAR II station.

The average air temperatures of trajectories with the same $t_{\text {hol }}$ were averaged again for each value of $t_{\text {hol }}$. Colours of markers indicate the averaged air temperature in Fig. 2. The average temperatures of trajectories arriving at the two stations tended to be higher with longer over-land travel times, and this tendency was more pronounced for the SMEAR I station. This feature can be attributed to the heat transfer from the continental land mass to the air parcel, and the weaker relation between $t_{\text {hol }}$ and temperature at the SMEAR II station could be explained by the fact that air masses arriving at SMEAR II needed to undergo the passage over the Baltic Sea. Very quick transit to SMEAR II resulted in low temperatures $\left(t_{\mathrm{hol}}<18 \mathrm{~h}\right)$. Overall, we could reproduce the findings by Tunved et al. (2008).

\subsubsection{Accumulated monoterpene emissions}

We classified all the trajectories by grouping them according to their average trajectory temperature into five temperature bins from 0 to $20^{\circ} \mathrm{C}$ for both stations. The accumulated monoterpene emissions along trajectories as a function of $t_{\text {hol }}$ were calculated in each temperature bin, and their values versus $t_{\text {hol }}$ are plotted in Fig. 3 for both stations. The figure demonstrates the effect of $t_{\text {hol }}$ and air temperature on the monoterpene emissions, and one can clearly see the dependence between temperature and monoterpene emissions. The accumulated monoterpene emissions at the SMEAR II station were slightly higher than those at the SMEAR I station, yet of the same order of magnitude. The data in the temperature bin $16-20^{\circ} \mathrm{C}$ at the SMEAR I station were very limited, so we neglected this temperature bin in the following analysis.

\subsection{Aerosol dynamics and $\mathrm{CCN}$ formation}

As can be seen from the results in the previous section, the observed aerosol at our receptor stations depended on the time in which the air parcel had travelled over the boreal forest area, whereas the air temperature during this transport 


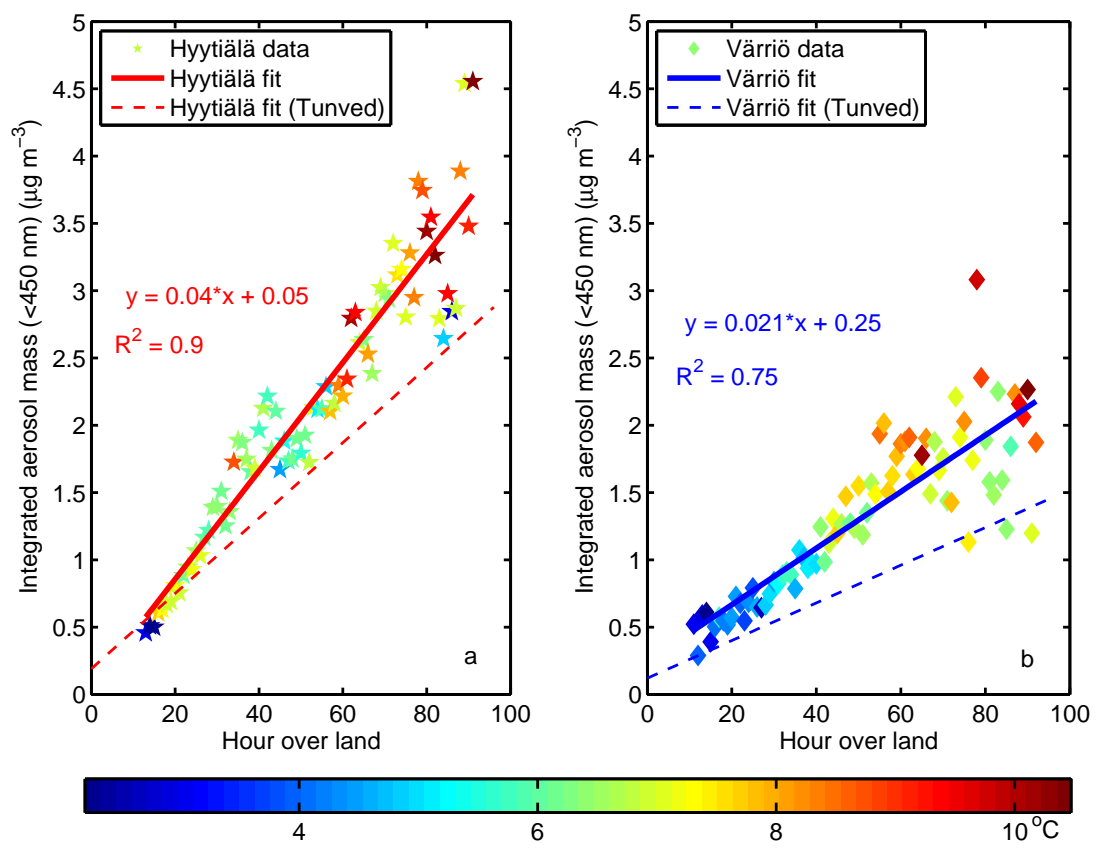

Figure 2. Average aerosol mass (particle size smaller than $450 \mathrm{~nm}$ ) vs. travelling hour over land of trajectories (a) at the SMEAR II station, and (b) at the SMEAR I station. Solid lines represent linear fits from data. Fitting slopes and their intercepts are written in the equations, together with their coefficients of determination $\left(R^{2}\right)$. Marker colours indicate the averaged temperature at each hour over land. The dashed lines are fitting slopes reported from Tunved et al. (2006) at these two stations.

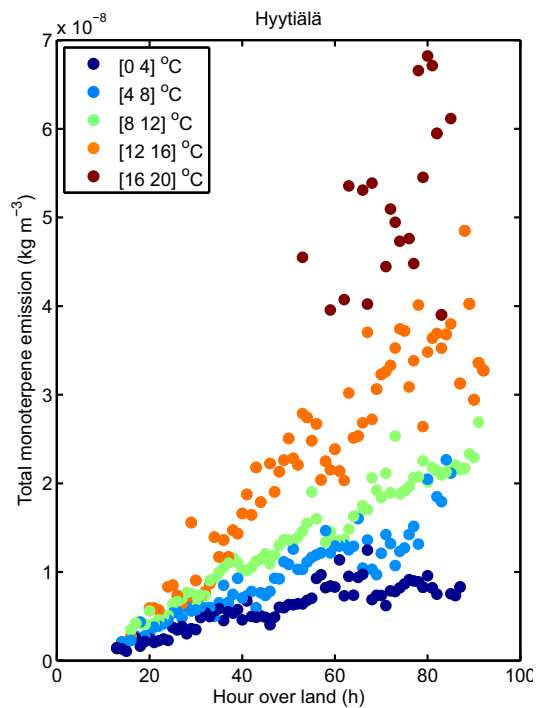

(a)

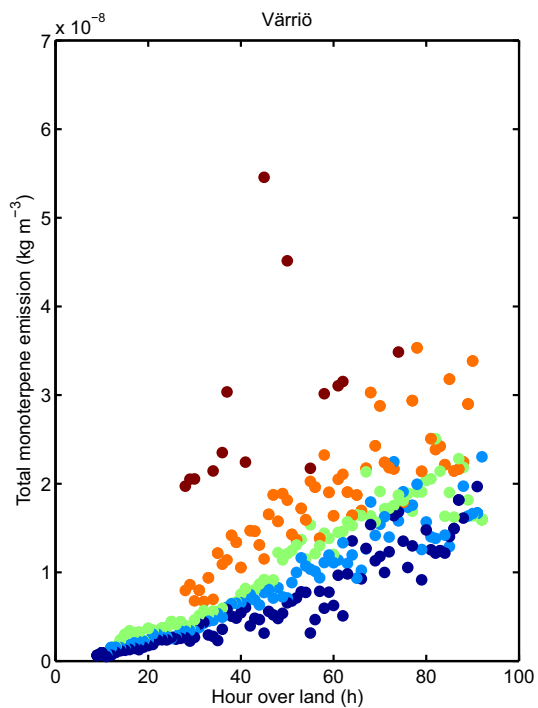

(b)

Figure 3. Accumulated total monoterpene emissions as a function of hour over land (a) at the SMEAR II station, and (b) at the SMEAR I station. The marker colours of legends represent the same binned temperature in both sub-figures.

affected the amount of the assumed aerosol precursor (biogenic monoterpenes) emitted into the air parcel. Therefore, we studied the evolution of the average observed aerosol size distribution as a function of travelled time over land, and we also looked into the temperature dependence of this evo- lution. Additionally, we investigated the number concentrations of aerosol particles in three different size ranges. 

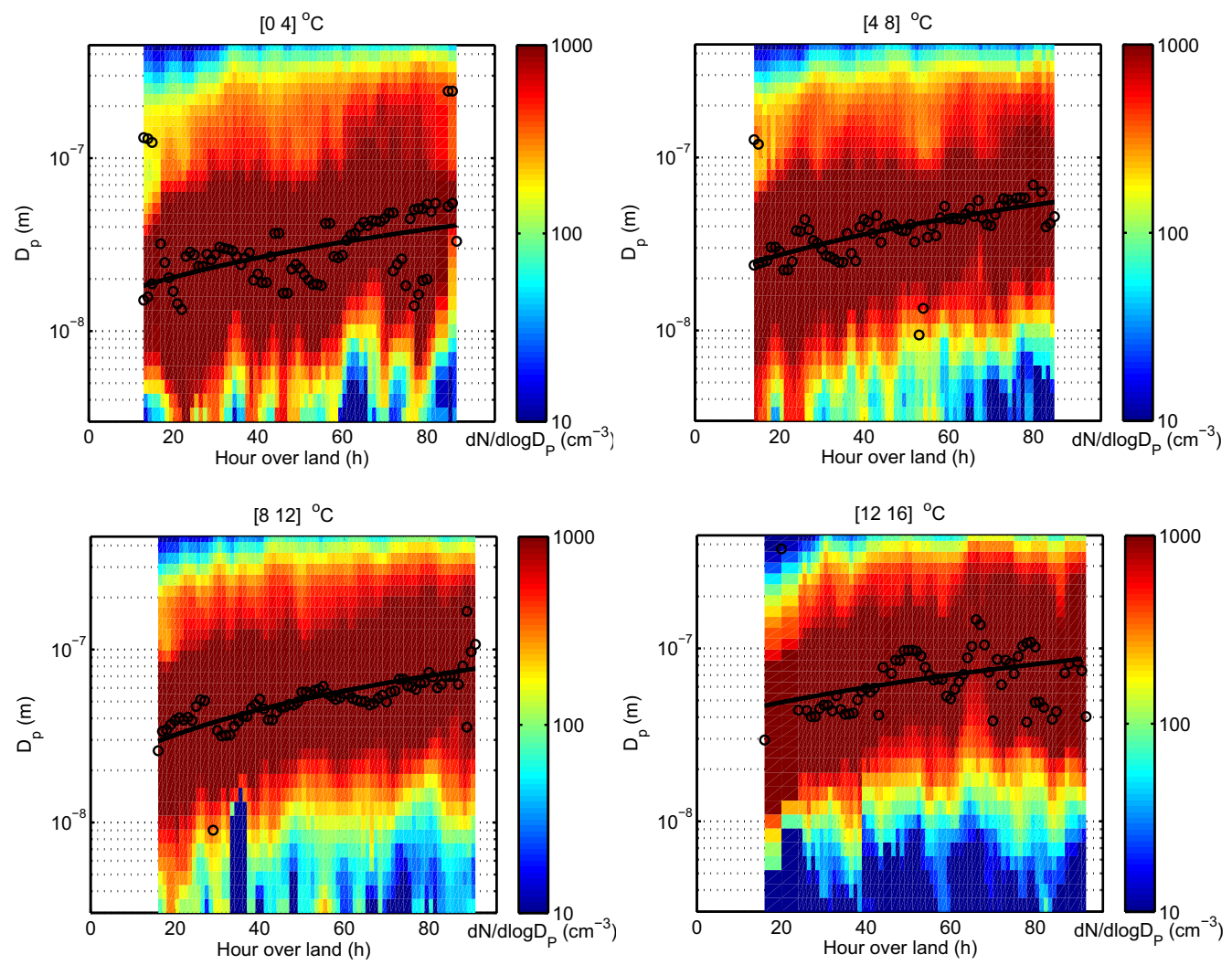

Figure 4. Aerosol particle-size distributions as a function of hour over land in the first four temperature bins at the SMEAR II station, Hyytiälä. The black circles are the maxima of the normal size distribution function at each hour, and black line depicts the mode fitting.

\subsubsection{Evolution of particle-size distributions}

We computed the average aerosol size distribution for each $t_{\mathrm{hol}}$ bin. The resulting average-size evolution distributions in relation to $t_{\text {hol }}$ in the first four temperature bins are depicted both for the SMEAR II station (Fig. 4) and SMEAR I station (Fig. 5). In each sub-figure of Figs. 4 and 5, a normal distribution function was fitted to each $t_{\text {hol }}$ for all the three particlesize modes, and the maxima at each fitting mode were then calculated, seen from the black circles in all sub-figures. A linear fitting to the hour over land corresponding to the maxima of particle number concentrations at dominant Aitken or accumulation mode was made, which gives the growth rate of particles determined by different $t_{\text {hol }}$ in unit $\mathrm{nm} \mathrm{h}^{-1}$. The average growth rates are listed in Table 1, together with the initial and ending diameter of particles during the growth. In addition, the initial and ending particle diameters were extrapolated to the same $t_{\mathrm{hol}}$ at the $t_{\mathrm{hol}}=10 \mathrm{~h}$ for comparison.

Figures 4 and 5 indicate that new aerosol particles had been formed when clean air masses entered the northern boreal forest area, and that the newly-formed particles grew to sizes of $20 \mathrm{~nm}$, on average, after $10 \mathrm{~h}$ of $t_{\mathrm{hol}}$, regardless of temperature. By looking at extrapolated particle sizes at $t_{\text {hol }}=10 \mathrm{~h}$ in the first four temperature bins in Table 1 , we can see that the particle growth from the nucleation mode to Aitken mode clearly accelerated with increasing temperatures.

A continuous growth of the particles to the Aitken and accumulation mode as a function of $t_{\text {hol }}$ can be seen from all sub-figures at both stations, but the formation of new particles was not apparent in the average size distributions after $20 \mathrm{~h}$ of $t_{\text {hol }}$. The average growth rate of the Aitken and accumulation mode particles was $0.43 \mathrm{~nm} \mathrm{~h}^{-1}$ at the SMEAR II station and $0.56 \mathrm{~nm} \mathrm{~h}^{-1}$ at SMEAR I station, similar to the growth rates reported by Tunved et al. (2006). The growth rate increased clearly with the increasing temperature at both stations (from $0.31 \mathrm{~nm} \mathrm{~h}^{-1}$ in the temperature bin 0 $4{ }^{\circ} \mathrm{C}$ to $1.58 \mathrm{~nm} \mathrm{~h}^{-1}$ in the temperature bin $16-20^{\circ} \mathrm{C}$ at the SMEAR II station, and from $0.37 \mathrm{~nm} \mathrm{~h}^{-1}$ in the temperature bin $0-4{ }^{\circ} \mathrm{C}$ to $0.84 \mathrm{~nm} \mathrm{~h}^{-1}$ in the temperature bin $12-16^{\circ} \mathrm{C}$ at the SMEAR I station). Several previous studies (Dal Maso et al., 2005, 2007; Yli-Juuti et al., 2011) have shown that growth rates were higher during warmer season and our results are in line with these observations. The increase in the growth rate implicates an increase in the concentration of condensable vapours, as expected from the temperature dependence of the emissions of precursor organics. Therefore, our studies are in line with the assumption that monoterpenes are the main gas precursors for aerosol growth. The average growth rate we observed is lower than growth rates observed 

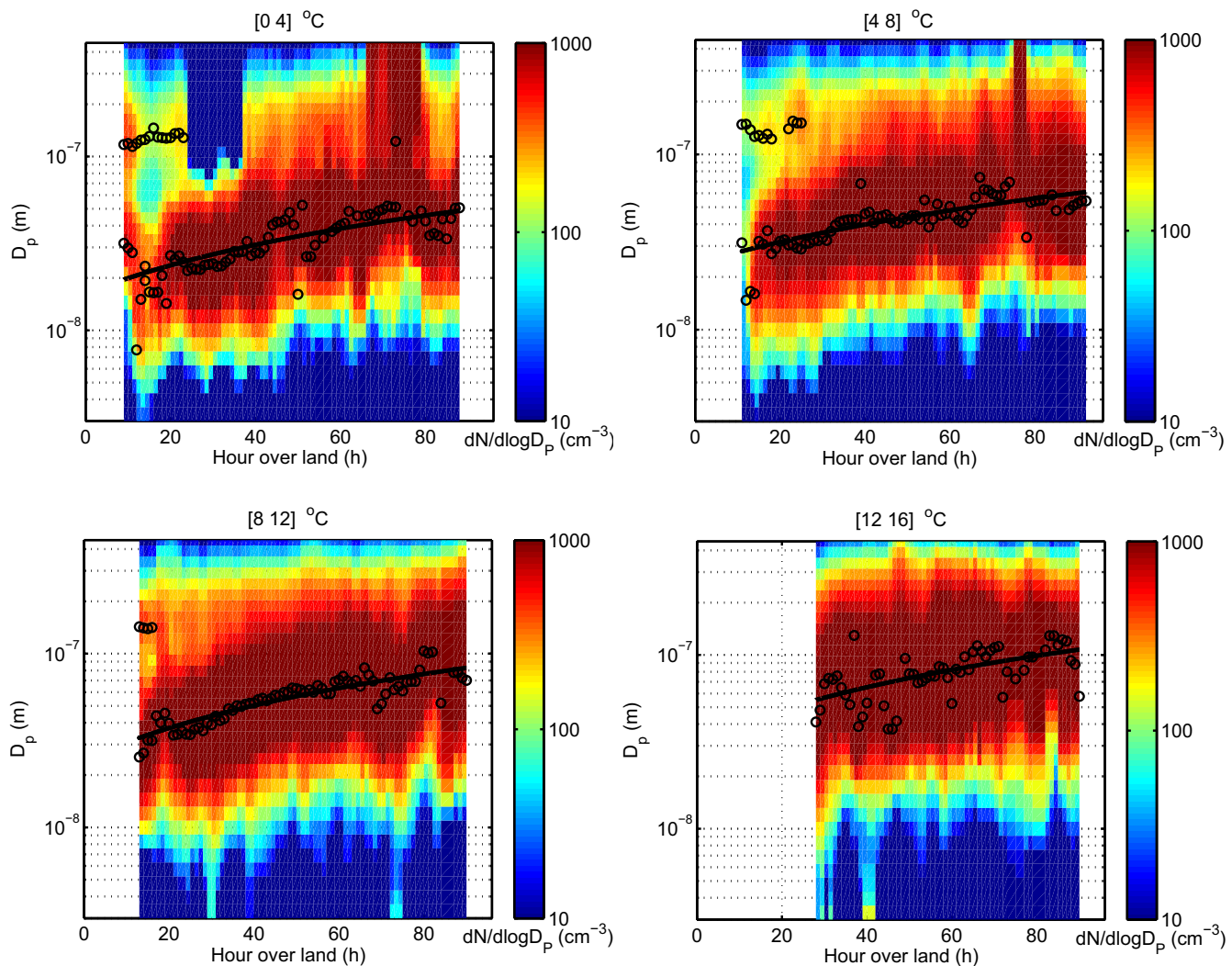

Figure 5. Aerosol particle-size distributions as a function of hour over land in the first four temperature bins at the SMEAR I station, Värriö. The black circles are the maxima of the normal size distribution function at each hour, and black line depicts the mode fitting.

from point measurements at single observation stations for particle formation events (Dal Maso et al., 2005; Yli-Juuti et al., 2011). This is due to the fact that our growth rates were averaged from the whole data set, while growth rates in other studies have been taken only from selected days with clear, new particle-formation events. Such days are likely to have above-average condensing vapour concentrations.

The condensation sink (CS) determines the speed of precursor molecules condensing onto the pre-existing aerosol particles, and is strongly dependent on the aerosol size distribution (Lehtinen et al., 2003). The median CS values were calculated from the evolution of aerosol size distributions as a function of $t_{\text {hol }}$ in all temperature bins for both stations, and their values are also included in Table 1. The CS increased with temperature and was higher at the SMEAR II station compared to the SMEAR I station in the same temperature bins.

\subsubsection{Particle number concentrations at three size modes versus monoterpene emissions}

Nucleation mode particles are the seeds of BSOA. To investigate the response of newly formed nucleation mode particles to the temperature along trajectories, the nucleation mode particle number concentrations against total accumu- lated monoterpene emissions in these five temperature bins are depicted both for the SMEAR II station (Fig. 6a) and the SMEAR I station (Fig. 6b). In both figures, each data point includes the averaged nucleation mode particle number concentration and accumulated monoterpene emission from trajectories travelling the same $t_{\mathrm{hol}}$ in each temperature bin, and marker colours demonstrate temperature bins in all subfigures.

The nucleation mode particle number concentrations showed a negative correlation with the accumulated monoterpene emissions at both stations. This is connected to the occurrence of new particle formation after longer travel times; it is likely that nucleation was suppressed by the high values of CS resulting from particle growth caused by the monoterpene emissions that have been oxidised and grown the particles through air mass transport. The average number of nucleation mode particles was lower when the average trajectory temperature was higher. However, when comparing the number of nucleation mode particles at similar levels of cumulative monoterpene emissions, no clear dependence on the trajectory temperature could be observed. The available data do not support the idea that air temperature itself would influence the nucleation mode particle production process. Rather, a possible temperature dependence of nucleation mode particle concentration can be interpreted as 

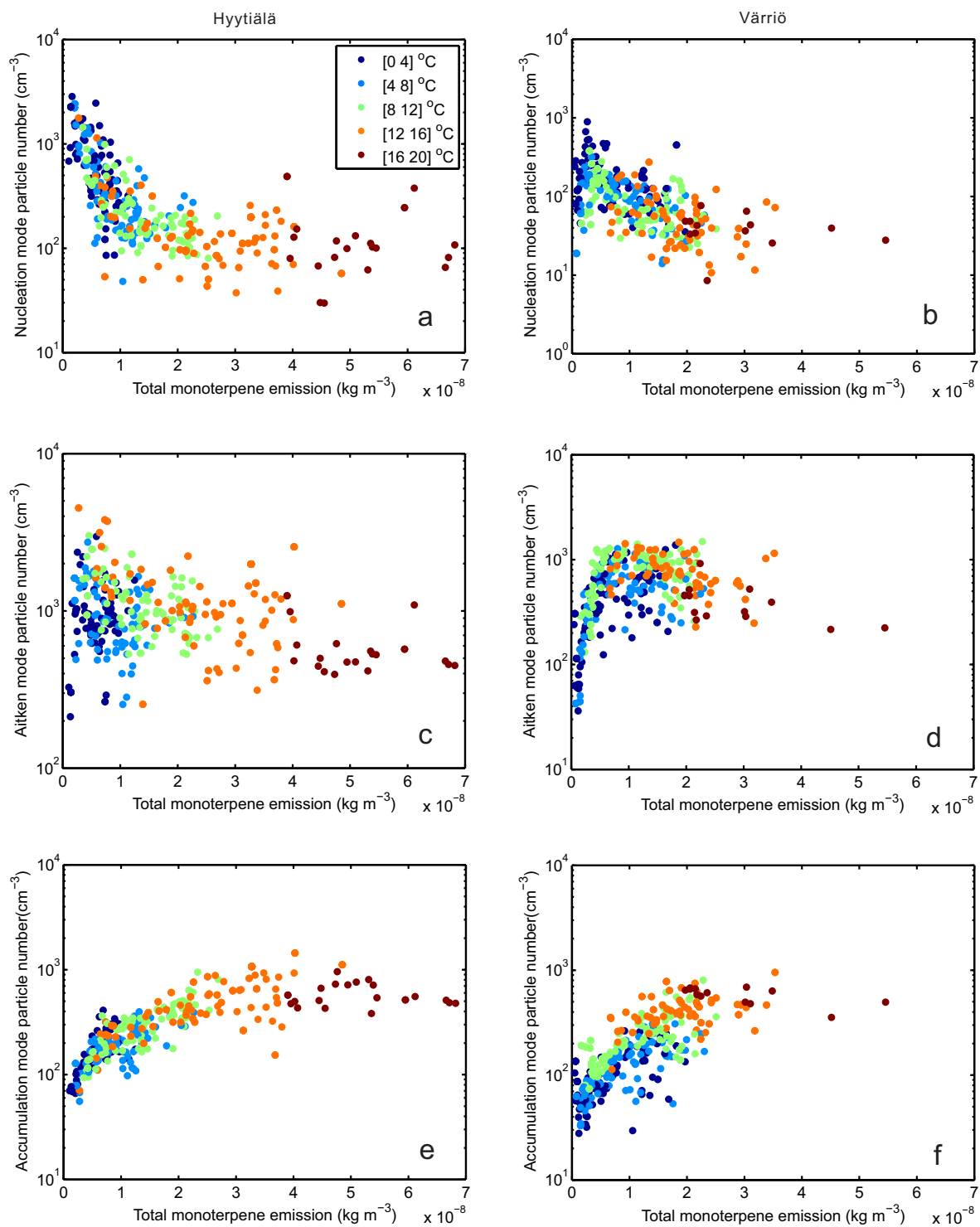

Figure 6. Nucleation mode particle number concentrations vs. total monoterpene emissions among the five temperature bins (a) at the SMEAR II station, and (b) at the SMEAR I station. Aitken mode particle number concentrations vs. total monoterpene emissions (c) at the SMEAR II station, and (d) at the SMEAR I station. Accumulation mode particle number concentrations vs. total monoterpene emissions (e) at the SMEAR II station, and (f) at the SMEAR I station. The marker colours of legends represent the same binned temperatures in all sub-figures.

a reflection of the feedback between the increased CS and the particle growth rate; new particles are formed mainly when CS is low, and when CS is high, condensing vapour contributes to aerosol mass formation, but new particles are not formed. Overall, the nucleation mode particle number concentration at the SMEAR II station was about 2-3 times higher than that at the SMEAR I station.

Particles growing continuously to the Aitken mode and accumulation mode are climatically important, as they can be activated as CCN, and further form cloud droplets (e.g. Kerminen et al., 2012). In order to examine temperature impacts on $\mathrm{CCN}$-sized particles formed along trajectories, par- ticle number concentrations in the Aitken and accumulation mode versus total accumulated monoterpene emissions in these five temperature bins are illustrated in Fig. 6 as the last four sub-figures for both stations. The average particle number concentrations in the Aitken mode did not change clearly with the increasing temperature, but rather scattered around the average in each temperature bin. The particle number concentrations in the accumulation mode showed a clear positive dependence on the monoterpene emissions and temperature at both stations, but the slopes between accumulation mode particle number concentrations and accumulated monoterpene emissions became smaller with the 


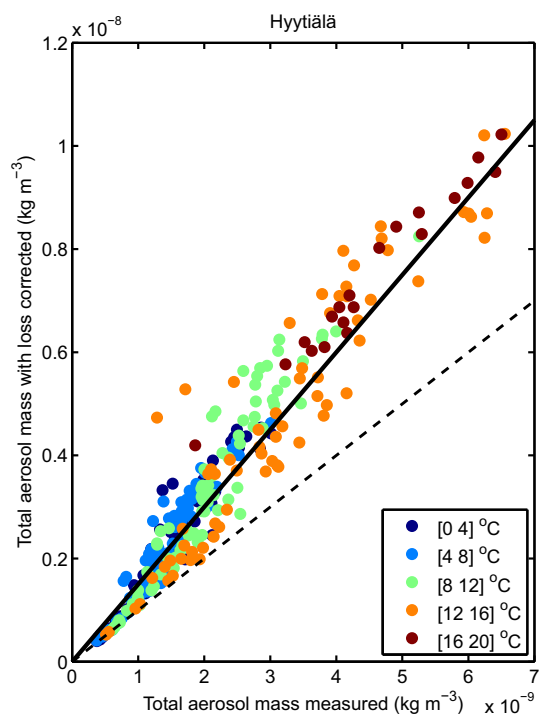

(a)

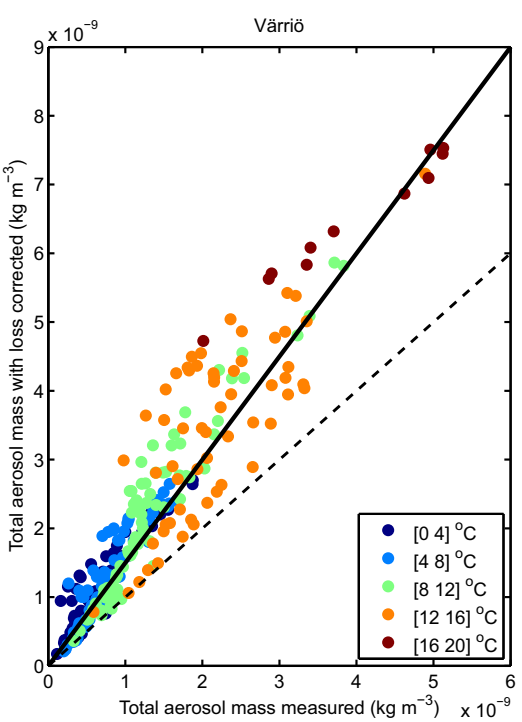

(b)

Figure 7. Total aerosol masses with deposition loss corrected vs. aerosol masses "observed" at (a) the SMEAR II station, and (b) at the SMEAR I station. The marker colours of legends represent the same binned temperatures. The dashed line indicates $1: 1$ ratio, and the solid line is the $1.5: 1$ ratio.

increased temperature. The projected maxima of the accumulation mode particle numbers can be seen ca. $1500 \mathrm{~cm}^{-3}$ for both stations. Nevertheless, it is certain that more particles had grown to the accumulation mode at higher temperatures during transport, so more particles may be activated as $\mathrm{CCN}$ at higher temperatures.

When investigating the particle concentrations in the light of both monoterpene emissions and temperature, temperature showed an indirect effect. For a given monoterpene concentration, the concentrations of Aitken and accumulation mode particles varied within the same bounds, with higher temperatures leading to higher particle concentrations in the studied size ranges. This effect was more pronounced at the SMEAR I station. Our data do not show clear evidence of the temperature directly affecting particle concentrations via, for example, lowering saturation vapour concentrations of condensing species. Rather, the average concentration of particles in the larger size ranges seems to be determined by the amount of monoterpenes emitted into the air mass, which is dependent on temperature.

\subsubsection{Particle loss from particle-size distribution evolution}

BSOA formation is often discussed in terms of aerosol yield (Hallquist et al., 2009; Odum et al., 1996), which is generally defined as the fraction of oxidized precursors entering the aerosol phase via condensation or equilibrium partitioning (Pankow, 1994; Hallquist et al., 2009). In order to estimate the aerosol yield, assuming monoterpene as the sole precursor in this study, we needed an estimate for the amount of aerosol that was mass produced during transport to the receptor stations, as well as aerosol losses during transport. We estimated these losses using a simplified aerosol lifetime calculation, where the aerosol loss as a function of sizes in each $t_{\text {hol }}$ was derived from the following discrete deposition equation:

$\frac{\mathrm{d} N_{i, \text { loss }}(t)}{\mathrm{d} t}=\gamma N_{i}(t)$.

Here, $\gamma$ is the size-dependent particle deposition rate $\left(\mathrm{h}^{-1}\right)$, $\mathrm{d} N_{i, \text { loss }}$ is the number of deposited particles at size bin $D_{\mathrm{p}_{i}}$, and $\mathrm{d} t=1(\mathrm{~h})$ in this case. We used the reverse aerosol lifetimes determined by Williams et al. (2002) in the mixed layer $(0-1 \mathrm{~km})$ as the average atmospheric aerosol loss rate in this study, and interpolated it to the size range of our DMPS measurements. This approach takes into account all the particle loss (dry deposition) mechanisms inside the boundary layer, including their impaction and diffusion losses to the surface. The used values of aerosol lifetimes are similar to another study by Riuttanen et al. (2013). The total deposition loss of aerosol mass $\left(\mathrm{d} M_{\text {loss }}(t)\right)$ in each $t_{\text {hol }}$ can then be estimated by the particle-size distributions of deposited particles, assuming spherical particles and using the same particle density. Therefore, the summation of particle mass losses from all hours of $t_{\text {hol }}\left(\sum_{T_{\text {end }}}^{T_{\text {start }}} d M_{\text {loss }}(t)\right)$, together with the measured total particle mass at the receptor stations, reveals the total amount of BSOA formed during air mass transport. The total aerosol masses with deposition loss corrected against the measured aerosol masses are plotted in Fig. 7 for both stations. It is noticeable that about one third of the particle mass 


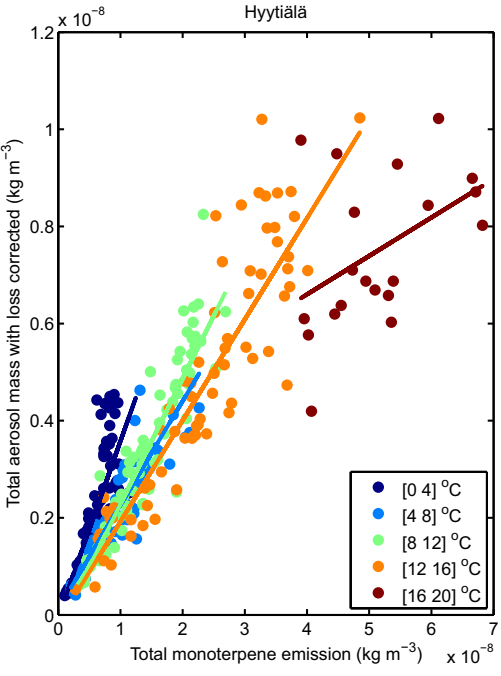

(a)

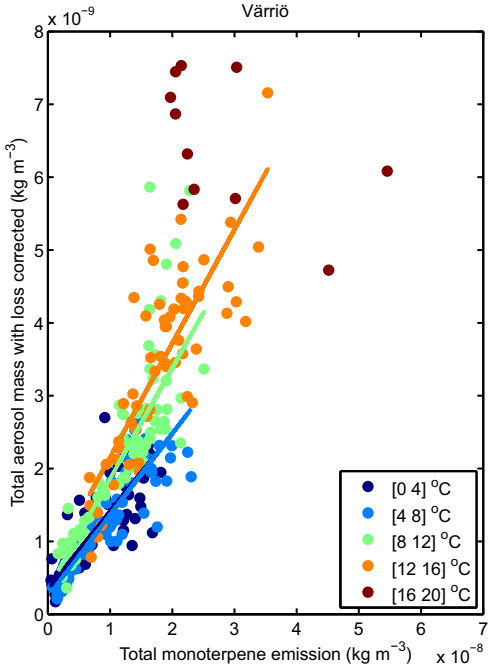

(b)

Figure 8. Total aerosol masses with deposition loss corrected vs. total monoterpene emissions among the five temperature bins (a) at the SMEAR II station, and (b) at the SMEAR I station. The marker colours of legends represent the binned temperatures. Solid lines depict fitting slopes between these two quantities at each temperature bin.

was lost during the transport. Hence, it is important to include aerosol losses in the next calculation of aerosol yield.

\subsection{Temperature influence on the apparent aerosol yield}

The formation process of BSOA generally includes gasphase oxidation of monoterpenes and other compounds at first, and gas-particle partitioning secondly (Hallquist et al., 2009). Monoterpenes are highly reactive to the major atmospheric oxidants (e.g. ozone, $\mathrm{OH}$, and $\mathrm{NO}_{3}$ ), so it can be approximated that nearly all monoterpenes have undergone primary atmospheric oxidation before arriving at the receptor stations when the imaginary air parcel is being transported by air mass transport. A certain fraction of the lowvolatility oxidation products of monoterpenes can condense onto the formed particles through gas-particle partitioning, which increases aerosol sizes and mass. Therefore, a simplified aerosol mass gain in the imaginary air parcel can be linked to the certain fraction of the condensable monoterpene oxidation products accumulating along the trajectory. The value of this certain fraction, i.e. the ratio between the total aerosol mass and the cumulative monoterpene emission, was defined as the apparent aerosol yield from oxidation of monoterpene emissions along trajectories in this study.

The total aerosol masses corrected with deposition loss and accumulated monoterpene emissions were calculated from the grouped trajectories in each temperature bin (Fig. 8). The apparent aerosol yields were then obtained from linear fittings between these two quantities. The values of apparent aerosol yield in each temperature bin are depicted in Fig. 9 for both stations. At the SMEAR II station, the appar-

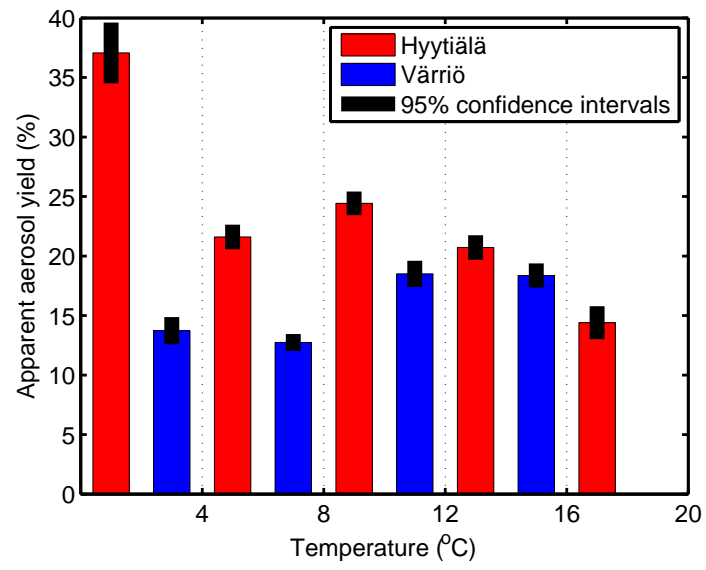

Figure 9. Estimated aerosol yield (i.e. the direct fitting slope between aerosol mass and total monoterpene emission) in five temperature bins both at the SMEAR I station (blue bars) and the SMEAR II station (red bars). The black bars indicate $95 \%$ confidence intervals from the fitting slopes at both stations.

ent aerosol yield decreased with an increasing temperature from the highest $37.1 \%$ yield in the temperature bin $0-4{ }^{\circ} \mathrm{C}$ to $14.4 \%$ yield in the temperature bin $16-20^{\circ} \mathrm{C}$. The average aerosol yield at the SMEAR I station differed from that at the SMEAR II station, where it was 13.7 and $12.7 \%$ in the first two temperature bins, and slightly increased to 18.5 and $18.4 \%$ in the next two temperature bins.

The variation in the estimated apparent aerosol yields was quite large as a function of the simple temperature parameter and site, which clearly shows that using a simple 
parameterization based on monoterpenes is not a sufficiently accurate method to model background BSOA formation. Two features are evident in the yield estimations: firstly, aerosol mass production in cooler temperatures is more efficient for the SMEAR II station, and the efficiency of VOC transformation is higher at this more southern station. At higher average trajectory temperatures, the apparent aerosol yield from monoterpenes at both stations started to approach values close to each other.

The difference between the SMEAR I and SMEAR II stations at low temperatures is difficult to attribute directly to any single cause. It is known from previous studies (e.g. Dal Maso et al., 2008) that particle number concentrations tend to follow different annual cycles at these two stations, especially in the lower particle-size range. The analysis of a damped temperature sum parameter has shown that the damped temperature sum value close to zero leads to elevated new particle formation rates and small-particle concentrations (Dal Maso et al., 2009), which was speculated to be caused by spring recovery of trees leading to biogenic emissions with a higher potential to nucleate. As it has been shown that the mixture of biogenic emissions has a clear effect on BSOA formation rate, also in terms of the particle mass (Mentel et al., 2009), it can be argued that biogenic emissions at low temperatures have a different chemical mixture. However, since such an effect would be expected to be visible also for the SMEAR I station, this explanation cannot be generalized.

Due to its closer proximity to athropogenic sources compared with SMEAR I, air masses arriving at SMEAR II were probably more influenced by such sources. While our selection of the time period was performed so that winter- and spring-time periods which showed elevated $\mathrm{SO}_{2}$ concentrations (Lyubovtseva et al., 2005) were screened out, it is possible that emissions from e.g. combustion activities add influence to aerosol mass formation during air mass transport.

The apparent aerosol yield in our study is higher than the previous found by Tunved et al. (2008), mainly because particle mass losses have been taken into account, yet it is still higher than the BSOA yield from some plant chamber experiments, e.g. $1.9-17.7 \%$ by Hao et al. (2011), and 5-10\% from Mentel et al. (2009). However, model studies on SOA yields have shown much higher variations and uncertainties, ranging from several percentages up to $70 \%$ (Hallquist et al., 2009).

Our estimate for the aerosol yield over a boreal forest area is, to our knowledge, the first attempt to obtain an average SOA mass yield assuming monoterpenes as the SOA precursor. The results, which show a large variation both between sites and as a function of temperature, demonstrate that applying a simple parameterization for the mass yield will not describe SOA formation adequately. The estimated apparent mass yield from monoterpenes ranged between 13 and $37 \%$, with higher yields obtained for the SMEAR II station, influenced more by anthropogenic sources.

\section{Summary and conclusion}

We extended earlier studies to evaluate the potential temperature impacts on the natural aerosol dynamics and mass yield from biogenic momoterpene emissions among northern boreal forest area, using long-term field measurements of aerosol size distributions and back trajectories at two Finnish SMEAR stations. We found that nucleation prefers to take place in originally clean marine air masses after they have arrived at the boreal forest area. The newly formed particles were found to continuously grow to the Aitken mode and further to the accumulation mode during air mass transport, and the nucleation process tends to cease within a day or so of air mass transport over land.

Our results suggest that the "averaged air parcel history" method can be used to obtain valuable information on the development of aerosol over the boreal forest area. For the first time, we showed that both travel time over land and air temperature influenced the evolution of the natural aerosol.

Nucleation mode particle number concentrations were higher at lower temperatures, whereas particle number concentrations in the accumulation mode were slightly higher at warmer temperatures. This suggests more efficient $\mathrm{CCN}$ production associated with BSOA formation at higher temperatures, in line with Paasonen et al. (2013). No clear evidence of temperature directly affecting particle production process could be observed, but rather particle number concentrations were determined by the amount of monoterpenes emitted into the air mass, which was dependent on temperature.

The apparent aerosol yield derived from the aerosol masses against accumulated monoterpene emissions along trajectories was of the order of $13-37 \%$ with a minor, yet opposite, temperature dependence between these two stations. Overall, our study suggests that the temperature dependence of BSOA production should be treated with caution, and a simple parameterization should be especially avoided in predicting the aerosol production potential from rising temperatures in future. Further investigation on the detailed processes of BSOA yield as a function of temperature would be necessary to reveal the actual aerosol distribution and its climate effects.

Acknowledgements. The Authors wish to thank the Maj and Tor Nessling foundation for financial support (grant No. 2009362), as well as Academy of Finland Center of Excellence program (project number 1118615). We also thank the Nordic Centre of Excellence CRAICC (Cryosphere-atmosphere interactions in a changing Arctic climate) for support.

Edited by: S. M. Noe 


\section{References}

Arneth, A., Harrison, S. P., Zaehle, S., Tsigaridis, K., Menon, S., Bartlein, P. J., Feichter, J., Korhola, A., Kulmala, M., O’Donnell, D., Schurgers, G., Sorvari, S., and Vesala, T.: Terrestrial biogeochemical feedbacks in the climate system, Nat. Geosci., 3, 525532, 2010.

Bertin, N., Staudt, M., Hansen, U., Seufert, G., Ciccioli, P., Foster, P., Fugit, J. L., and Torres, L.: Diurnal and seasonal course of monoterpene emissions from Quercus ilex (L.) under natural conditions - Applications of light and temperature algorithms, Atmos. Environ., 31, 135-144, 1997.

Carslaw, K. S., Boucher, O., Spracklen, D. V., Mann, G. W., Rae, J. G. L., Woodward, S., and Kulmala, M.: A review of natural aerosol interactions and feedbacks within the Earth system, Atmos. Chem. Phys., 10, 1701-1737, doi:10.5194/acp-10-17012010, 2010.

Dal Maso, M., Kulmala, M., Riipinen, I., Wagner, R., Hussein, T., Aalto, P. P., and Lehtinen, K. E. J.: Formation and growth of fresh atmospheric aerosols: eight years of aerosol size distribution data from SMEAR II, Hyytiala, Finland, Boreal Environ. Res., 10, 323-336, 2005.

Dal Maso, M., Sogacheva, L., Aalto, P. P., Riipinen, I., Komppula, M., Tunved, P., Korhonen, L., Suur-Uski, V., Hirsikko, A., Kurten, T., Kerminen, V.-M., Lihavainen, H., Viisanen, Y., Hansson, H.-C., and Kulmala, M.: Aerosol size distribution measurements at four Nordic field stations: identification, analysis and trajectory analysis of new particle formation bursts, Tellus B, 59, 350-361, 2007.

Dal Maso, M., Hyvaerinen, A., Komppula, M., Tunved, P., Kerminen, V.-M., Lihavainen, H., Viisanen, Y., Hansson, H.-C., and Kulmala, M.: Annual and interannual variation in boreal forest aerosol particle number and volume concentration and their connection to particle formation, Tellus B, 60, 495-508, 2008.

Dal Maso, M., Hari, P., and Kulmala, M.: Spring recovery of photosynthesis and atmospheric particle formation, Boreal Environ. Res., 14, 711-721, 2009.

Day, M. C. and Pandis, S. N.: Predicted changes in summertime organic aerosol concentrations due to increased temperatures, Atmos. Environ., 45, 6546-6556, 2011.

Dentener, F. J., Carmichael, G. R., Zhang, Y., Lelieveld, J., and Crutzen, P. J.: Role of mineral aerosol as a reactive surface in the global troposphere, J. Geophys. Res.-Atmos., 101, 2286922889, 1996.

Donahue, N. M., Henry, K. M., Mentel, T. F., Kiendler-Scharr, A., Spindler, C., Bohn, B., Brauers, T., Dorn, H. P., Fuchs, H., Tillmann, R., Wahner, A., Saathoff, H., Naumann, K. H., Mohler, O., Leisner, T., Muller, L., Reinnig, M. C., Hoffmann, T., Salo, K., Hallquist, M., Frosch, M., Bilde, M., Tritscher, T., Barmet, P., Praplan, A. P., DeCarlo, P. F., Dommen, J., Prevot, A. S. H., and Baltensperger, U.: Aging of biogenic secondary organic aerosol via gas-phase $\mathrm{OH}$ radical reactions, P. Natl. Acad. Sci. USA, 109, 13503-13508, 2012.

Draxler, R. R. and Hess, G.: An overview of the HYSPLIT_4 modelling system for trajectories, Australian Meteorological Magazine, 47, 1998.

Draxler, R. R. and Hess, G. D.: Description of the Hysplit_4 modelling system, NOAA Tech Memorandum, ERL ARL-224, 1997.
Finlayson-Pitts, B. J. and Pitts, J. N.: Chemistry of the upper and lower atmosphere: theory, experiments, and applications, Academic Press, San Diego, CA, 2000.

Goldstein, A. H. and Galbally, I. E.: Known and unexplored organic constituents in the earth's atmosphere, Environ. Sci. Technol., 41, 1514-1521, 2007.

Guenther, A. B., Jiang, X., Heald, C. L., Sakulyanontvittaya, T., Duhl, T., Emmons, L. K., and Wang, X.: The Model of Emissions of Gases and Aerosols from Nature version 2.1 (MEGAN2.1): an extended and updated framework for modeling biogenic emissions, Geosci. Model Dev., 5, 1471-1492, doi:10.5194/gmd-51471-2012, 2012.

Hallquist, M., Wenger, J. C., Baltensperger, U., Rudich, Y., Simpson, D., Claeys, M., Dommen, J., Donahue, N. M., George, C., Goldstein, A. H., Hamilton, J. F., Herrmann, H., Hoffmann, T., Iinuma, Y., Jang, M., Jenkin, M. E., Jimenez, J. L., KiendlerScharr, A., Maenhaut, W., McFiggans, G., Mentel, T. F., Monod, A., Prevot, A. S. H., Seinfeld, J. H., Surratt, J. D., Szmigielski, R., and Wildt, J.: The formation, properties and impact of secondary organic aerosol: current and emerging issues, Atmos. Chem. Phys., 9, 5155-5236, doi:10.5194/acp-9-5155-2009, 2009.

Hao, L. Q., Romakkaniemi, S., Yli-Pirila, P., Joutsensaari, J., Kortelainen, A., Kroll, J. H., Miettinen, P., Vaattovaara, P., Tiitta, P., Jaatinen, A., Kajos, M. K., Holopainen, J. K., Heijari, J., Rinne, J., Kulmala, M., Worsnop, D. R., Smith, J. N., and Laaksonen, A.: Mass yields of secondary organic aerosols from the oxidation of alpha-pinene and real plant emissions, Atmos. Chem. Phys., 11, 1367-1378, doi:10.5194/acp-11-1367-2011, 2011.

Hari, P. and Kulmala, M.: Station for measuring ecosystematmosphere relations (SMEAR II), Boreal Environ. Res., 10, 315-322, 2005.

Heinzerling, D.: Automation of HYSPLIT trajectory generation and subsequent analysis, Washington University, Research for Undergraduates Program 2004, USA, 2004.

Hoyle, C. R., Boy, M., Donahue, N. M., Fry, J. L., Glasius, M., Guenther, A., Hallar, A. G., Hartz, K. H., Petters, M. D., Petaja, T., Rosenoern, T., and Sullivan, A. P.: A review of the anthropogenic influence on biogenic secondary organic aerosol, Atmos. Chem. Phys., 11, 321-343, doi:10.5194/acp-11-321-2011, 2011.

Kanakidou, M., Seinfeld, J. H., Pandis, S. N., Barnes, I., Dentener, F. J., Facchini, M. C., Van Dingenen, R., Ervens, B., Nenes, A., Nielsen, C. J., Swietlicki, E., Putaud, J. P., Balkanski, Y., Fuzzi, S., Horth, J., Moortgat, G. K., Winterhalter, R., Myhre, C. E. L., Tsigaridis, K., Vignati, E., Stephanou, E. G., and Wilson, J.: Organic aerosol and global climate modelling: a review, Atmos. Chem. Phys., 5, 1053-1123, doi:10.5194/acp-5-1053-2005, 2005.

Kerminen, V. M., Paramonov, M., Anttila, T., Riipinen, I., Fountoukis, C., Korhonen, H., Asmi, E., Laakso, L., Lihavainen, H., Swietlicki, E., Svenningsson, B., Asmi, A., Pandis, S. N., Kulmala, M., and Petaja, T.: Cloud condensation nuclei production associated with atmospheric nucleation: a synthesis based on existing literature and new results, Atmos. Chem. Phys., 12, 1203712059, doi:10.5194/acp-12-12037-2012, 2012.

Korhonen, H., Carslaw, K. S., Forster, P. M., Mikkonen, S., Gordon, N. D., and Kokkola, H.: Aerosol climate feedback due to decadal increases in Southern Hemisphere wind speeds, Geophys. Res. Lett., 37, L02805, doi:10.1029/2009GL041320, 2010. 
Kostenidou, E., Pathak, R. K., and Pandis, S. N.: An algorithm for the calculation of secondary organic aerosol density combining AMS and SMPS data, Aerosol Sci. Tech., 41, 1002-1010, 2007.

Kroll, J. H. and Seinfeld, J. H.: Chemistry of secondary organic aerosol: Formation and evolution of low-volatility organics in the atmosphere, Atmos. Environ., 42, 3593-3624, 2008.

Kulmala, M., Suni, T., Lehtinen, K. E. J., Dal Maso, M., Boy, M., Reissell, A., Rannik, U., Aalto, P., Keronen, P., Hakola, H., Back, J. B., Hoffmann, T., Vesala, T., and Hari, P.: A new feedback mechanism linking forests, aerosols, and climate, Atmos. Chem. Phys., 4, 557-562, doi:10.5194/acp-4-557-2004, 2004.

Kulmala, M., Nieminen, T., Chellapermal, R., Makkonen, R., Bäck, J., and Kerminen, V.-M.: Climate feedbacks linking the increasing atmospheric $\mathrm{CO}_{2}$ concentration, BVOC emissions, aerosols and clouds in forest ecosystems, Springer Netherlands, 489-508, doi:10.1007/978-94-007-6606-8_17, 2013.

Leaitch, W. R., Macdonald, A. M., Brickell, P. C., Liggio, J., Sjostedt, S. J., Vlasenko, A., Bottenheim, J. W., Huang, L., Li, S. M., Liu, P. S. K., Toom-Sauntry, D., Hayden, K. A., Sharma, S., Shantz, N. C., Wiebe, H. A., Zhang, W. D., Abbatt, J. P. D., Slowik, J. G., Chang, R. Y. W., Russell, L. M., Schwartz, R. E., Takahama, S., Jayne, J. T., and Ng, N. L.: Temperature response of the submicron organic aerosol from temperate forests, Atmos. Environ., 45, 6696-6704, 2011.

Lehtinen, K. E. J., Korhonen, H., Dal Maso, M., and Kulmala, M.: On the concept of condensation sink diameter, Boreal Environ. Res., 8, 405-411, 2003.

Lihavainen, H., Kerminen, V. M., Tunved, P., Aaltonen, V., Arola, A., Hatakka, J., Hyvärinen, A., and Viisanen, Y.: Observational signature of the direct radiative effect by natural boreal forest aerosols and its relation to the corresponding first indirect effect, J. Geophys. Res.-Atmos., 114, D20206, doi:10.1029/2009JD012078, 2009.

Lindfors, V., Rinne, J., and Laurila, T.: Upscaling the BIPHOREP Results - Regional Biogenic VOC Emissions in the European Boreal Zone, Tech. rep., Finnish Meteorological Institute, Air Quality Research, Sahaajankatu 20E, FIN-00810 Helsinki, Finland, 1999.

Lyubovtseva, Y. S., Sogacheva, L., Dal Maso, M., Bonn, B., Keronen, P., and Kulmala, M.: Seasonal variations of trace gases, meteorological parameters, and formation of aerosols in boreal forests, Boreal Environ. Res., 10, 493-510, 2005.

Makkonen, R., Asmi, A., Kerminen, V. M., Boy, M., Arneth, A., Guenther, A., and Kulmala, M.: BVOC-aerosol-climate interactions in the global aerosol-climate model ECHAM5.5-HAM2, Atmos. Chem. Phys., 12, 10077-10096, doi:10.5194/acp-1210077-2012, 2012.

Mentel, T. F., Wildt, J., Kiendler-Scharr, A., Kleist, E., Tillmann, R., Dal Maso, M., Fisseha, R., Hohaus, T., Spahn, H., Uerlings, R., Wegener, R., Griffiths, P. T., Dinar, E., Rudich, Y., and Wahner, A.: Photochemical production of aerosols from real plant emissions, Atmos. Chem. Phys., 9, 4387-4406, doi:10.5194/acp-94387-2009, 2009.

Miyazaki, Y., Jung, J., Fu, P. Q., Mizoguchi, Y., Yamanoi, K., and Kawamura, K.: Evidence of formation of submicrometer water-soluble organic aerosols at a deciduous forest site in northern Japan in summer, J. Geophys. Res.-Atmos., 117, D19213, doi:10.1029/2012JD018250, 2012.
Odum, J. R., Hoffmann, T., Bowman, F., Collins, D., Flagan, R. C., and Seinfeld, J. H.: Gas/particle partitioning and secondary organic aerosol yields, Environ. Sci. Technol., 30, 2580-2585, 1996.

Paasonen, P., Asmi, A., Petaja, T., Kajos, M. K., Aijala, M., Junninen, H., Holst, T., Abbatt, J. P. D., Arneth, A., Birmili, W. van der Gon, H. D., Hamed, A., Hoffer, A., Laakso, L., Laaksonen, A., Leaitch, W. R., Plass-Duelmer, C., Pryor, S. C., Raisanen, P., Swietlicki, E., Wiedensohler, A., Worsnop, D. R., Kerminen, V.-M., and Kulmala, M.: Warming-induced increase in aerosol number concentration likely to moderate climate change, Nat. Geosci., 6, 438-442, 2013.

Pankow, J. F.: An absorption-model of the gas aerosol partitioning involved in the formation of secondary organic aerosol, Atmos. Environ., 28, 189-193, 1994.

Quinn, P. K. and Bates, T. S.: The case against climate regulation via oceanic phytoplankton sulphur emissions, Nature, 480, 5156, 2011.

Riipinen, I., Pierce, J. R., Yli-Juuti, T., Nieminen, T., Hakkinen, S., Ehn, M., Junninen, H., Lehtipalo, K., Petaja, T., Slowik, J., Chang, R., Shantz, N. C., Abbatt, J., Leaitch, W. R., Kerminen, V. M., Worsnop, D. R., Pandis, S. N., Donahue, N. M., and Kulmala, M.: Organic condensation: a vital link connecting aerosol formation to cloud condensation nuclei (CCN) concentrations, Atmos. Chem. Phys., 11, 3865-3878, doi:10.5194/acp-11-38652011, 2011.

Riipinen, I., Yli-Juuti, T., Pierce, J. R., Petaja, T., Worsnop, D. R., Kulmala, M., and Donahue, N. M.: The contribution of organics to atmospheric nanoparticle growth, Nat. Geosci., 5, 453-458, 2012.

Riuttanen, L., Hulkkonen, M., Maso, M. D., Junninen, H., and Kulmala, M.: Trajectory analysis of atmospheric transport of fine particles, $\mathrm{SO}_{2}, \mathrm{NO}_{\mathrm{x}}$ and $\mathrm{O}_{3}$ to the SMEAR II station in Finland in 1996-2008, Atmos. Chem. Phys., 13, 2153-2164, doi:10.5194/acp-13-2153-2013, 2013.

Spracklen, D. V., Bonn, B., and Carslaw, K. S.: Boreal forests, aerosols and the impacts on clouds and climate, Philos. T. Roy. Soc. A, 366, 4613-4626, 2008.

Steinbrecher, R., Hauff, K., Rössler, J., Dürr, M., and Seufert, G.: Monoterpene emission from soils in orange plantations of the valencian citrus belt, Spain, Phys. Chem. Earth Pt. B, 24, 695698, 1999.

Tarvainen, V., Hakola, H., Hellén, H., Bäck, J., Hari, P., and Kulmala, M.: Temperature and light dependence of the VOC emissions of Scots pine, Atmos. Chem. Phys., 5, 989-998, doi:10.5194/acp-5-989-2005, 2005.

Tunved, P., Hansson, H. C., Kerminen, V. M., Strom, J., Dal Maso, M., Lihavainen, H., Viisanen, Y., Aalto, P. P., Komppula, M., and Kulmala, M.: High natural aerosol loading over boreal forests, Science, 312, 261-263, 2006.

Tunved, P., Stroem, J., Kulmala, M., Kerminen, V. M., Dal Maso, M., Svenningson, B., Lunder, C., and Hansson, H. C.: The natural aerosol over Northern Europe and its relation to anthropogenic emissions - implications of important climate feedbacks, Tellus B, 60, 473-484, 2008.

Williams, J., de Reus, M., Krejci, R., Fischer, H., and Ström, J.: Application of the variability-size relationship to atmospheric aerosol studies: estimating aerosol lifetimes and ages, Atmos. Chem. Phys., 2, 133-145, doi:10.5194/acp-2-133-2002, 2002. 
Yli-Juuti, T., Nieminen, T., Hirsikko, A., Aalto, P. P., Asmi, E., Horrak, U., Manninen, H. E., Patokoski, J., Dal Maso, M., Petaja, T., Rinne, J., Kulmala, M., and Riipinen, I.: Growth rates of nucleation mode particles in Hyytiala during 20032009: variation with particle size, season, data analysis method and ambient conditions, Atmos. Chem. Phys., 11, 12865-12886, doi:10.5194/acp-11-12865-2011, 2011.
Yu, F.: A secondary organic aerosol formation model considering successive oxidation aging and kinetic condensation of organic compounds: global scale implications, Atmos. Chem. Phys., 11, 1083-1099, doi:10.5194/acp-11-1083-2011, 2011. 